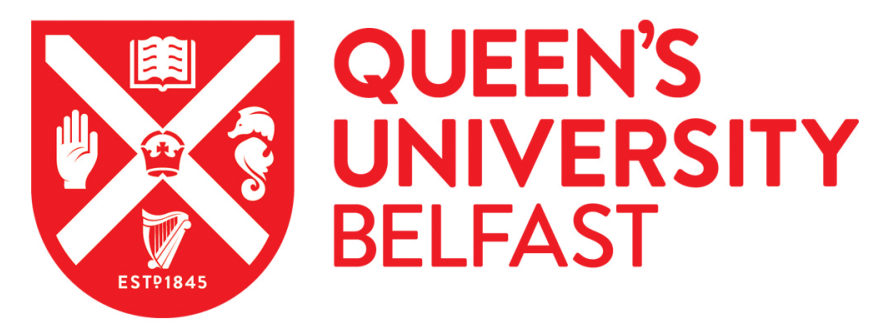

\title{
Low-dose radiation-induced risk in spermatogenesis
}

Fukunaga, H., Butterworth, K. T., Yokoya, A., Ogawa, T., \& Prise, K. M. (2017). Low-dose radiation-induced risk in spermatogenesis. International journal of radiation biology, 93(12), 1291-1298.

https://doi.org/10.1080/09553002.2017.1355579

\section{Published in:}

International journal of radiation biology

\section{Document Version:}

Peer reviewed version

Queen's University Belfast - Research Portal:

Link to publication record in Queen's University Belfast Research Portal

\section{Publisher rights}

2017 Informa UK Limited, trading as Taylor \& Francis Group.

This work is made available online in accordance with the publisher's policies. Please refer to any applicable terms of use of the publisher.

\section{General rights}

Copyright for the publications made accessible via the Queen's University Belfast Research Portal is retained by the author(s) and / or other copyright owners and it is a condition of accessing these publications that users recognise and abide by the legal requirements associated with these rights.

Take down policy

The Research Portal is Queen's institutional repository that provides access to Queen's research output. Every effort has been made to ensure that content in the Research Portal does not infringe any person's rights, or applicable UK laws. If you discover content in the Research Portal that you believe breaches copyright or violates any law, please contact openaccess@qub.ac.uk. 


\section{Low-dose radiation-induced risk in spermatogenesis}

Hisanori Fukunaga ${ }^{a}$, Karl T. Butterworth ${ }^{\mathrm{a}}$, Akinari Yokoya ${ }^{\mathrm{b}}$, Takehiko Ogawa ${ }^{c}$ and Kevin M. Prise ${ }^{a *}$

${ }^{a}$ Centre for Cancer Research and Cell Biology, Queen's University Belfast, Belfast, UK; ${ }^{b}$ Tokai Quantum Beam Science Center, National Institutes for Quantum and Radiological Science and Technology, Tokai, Japan; 'Institute of Molecular Medicine and Life Science, Yokohama City University Association of Medical Science, Yokohama, Japan

*corresponding author: Prof. Kevin M. Prise. Centre for Cancer Research and Cell Biology, Queen's University Belfast, 97 Lisburn Road, Belfast BT9 7AE, UK. E-mail: k.prise@qub.ac.uk 


\section{Low-dose radiation-induced risk in spermatogenesis}

Purpose: To discuss low-dose radiation-induced risks to male fertility focusing on potential mechanisms of low-dose radiation-induced damage on spermatogenesis, epidemiological studies of environmental radiation effects on sperm parameters and transgenerational effects from exposure of spermatogonial stem cells (SSCs).

Background: Spermatogenesis produces mature male gametes, spermatozoa, which fertilize their counterpart female gametes, oocytes. The robust maintenance system of sperm formation is essential for genomic conservation; however, male fertility can be easily damaged by exposure to environmental, chemical and physical factors including ionizing radiation. The testes are known to be relatively radiosensitive in the mammalian body yet the underlying molecular mechanisms of low-dose radiation-induced risks for spermatogenesis remain unclear. Furthermore, evidence characterising transgenerational effects following exposure of SSCs are controversial.

Conclusion: Current concerns about the possible effects on low-dose radiation exposure on spermatogenesis requires further elucidation that may be resolved comparing and integrating observed data from both epidemiological and experimental studies.

Keywords: low-dose radiation-induced risk; spermatogenesis; radiation-induced bystander signalling; transgenerational effect; Chernobyl nuclear accident; Fukushima nuclear accident

\section{Introduction}

Since Antonie van Leeuwenhoek's 1677 discovery of spermatozoa in a semen sample (Ruestow 1983; Egerton 2006), many studies have been conducted to better understand the process of spermatogenesis. Sperm production is one of the most complex processes in the male body which takes around 60 days from maturation of the spermatogonial stem cells (SSCs) to fully functional spermatozoa (Figure 1). This dynamic cell differentiation is also one of the most important processes responsible for the inheritance of life along 
with ovum formation in the female body. Mammalian spermatogenesis requires the maintenance of stem cell pool, amplification of spermatogonia, reductive division to haploid cells (meiosis) and the morphological transformation of the haploid cells into spermatozoa (spermiogenesis) (Clermont 1972; Griswold 2016).

Ionizing radiation is known to induce a broad spectrum of DNA lesions, including damage to the nucleotide bases, DNA and DNA-protein crosslinks, DNA single- and double-strand breaks (SSBs and DSBs). These lesions have significant consequences on biological systems by acting to trigger cell death or induce mutations in surviving cells leading to carcinogenesis (National Research Council (US) Committee on the Biological Effects of Ionizing Radiation (BEIR V) 1990; Little 2000). The first radiation-related solid cancer was reported in 1902, arising in an ulcerated area of the skin, and the first report of leukaemia was reported in five radiation workers in 1911 (Shah et al. 2012). From an early stage, animal model systems been applied to study the effects of radiation on genomic. In 1903, Heinrich Albers-Schönberg demonstrated that X-rays could damage rabbits' testes (Doll 1995). Hermann Muller, the 1946 Nobel laureate in Physiology or Medicine showed that X-rays cause mutations in fruit flies and the prevalence was approximately linearly to dose (Muller 1927). Following the atomic explosions in Hiroshima and Nagasaki in 1945, there was great public concern about the possible harmful effects of radiation exposure which led to several studies being conducted on radiation-induced health risks, particularly carcinogenesis (Little 2009; Douple et al. 2011; Kamiya et al. 2015).

Radiation-induced effects to biological systems extends far beyond carcinogenesis and includes causes of reproductive toxicity. The testes and the process of spermatogenesis are relatively hypersensitive to radiation (Withers et al. 1974; Meistrich et al. 1978) supported by the International Committee on the Radiological Protection 
(ICRP) report in 2007, giving the weighting factor of the gonads as 0.08 (International Commission on Radiological Protection 2007). The maintenance of human sperm production is highly robust; however, male fertility can be easily impacted by environmental, chemical and physical exposures including ionizing radiation. Data from a 1970s study conducted in prisoner volunteers who agree to have their testicles irradiated demonstrated effects on spermatogenesis in humans (Clifton \& Bremner 1983) where a dose of 0.11 Gy caused significant suppression of sperm count with doses of 3 to 5 Gy causing permanent sterility.

In recent clinical practice, the radiotherapy and chemo-radiotherapy may result in temporary, long-term or permanent gonadal toxicity in male patients (Rowley et al. 1974; Jeruss \& Woodruff 2009; Meistrich 2013). The fractionated radiation used in the treatment of cancer (often given in doses over 3-4 weeks) causes greater delays in spermatogenic recovery, for example, a total gonadal dose of $>2.5$ Gy fractionated radiation generally produces permanent azoospermia, whereas doses $>6$ Gy given as a single exposure are required (Meistrich 2013). These data confirmed deterministic effects on male germ cells with a threshold dose. Improved therapies for cancer and other conditions have resulted in a growing population of long-term survivors, however, infertility is an unfortunate side effect of some cancer therapies which significantly impacts the quality of life of survivors within their pre-reproductive or reproductive years (Valli et al. 2014). Nevertheless, modern day advanced radiotherapies have evolved to such an extent that strategies can be put in place to reduce potential risk of loss of fertility and the vast majority of male pelvic irradiations take place in elderly men. Currently, for younger reproductive males, no comprehensive studies have assessed the effects of focal therapies, e.g. high-intensity-focused ultrasound therapy, on male fertility. It is important that clinicians consider infertility when discussing the pros and cons of various cancer 
therapies in their younger patients (Jeruss \& Woodruff 2009; Tran et al. 2015).

Male reproductive potential continues to be adversely affected not only by clinical, but also environmental and occupational, radiation exposure (Sheiner et al. 2003; Bonde 2010; Mortimer et al. 2013). In the modern world, protection of sperm-forming cells from various radiation exposures is one of the most significant challenges to male fertility preservation (Moss et al. 2016). Since the large-scale nuclear disasters in Chernobyl, in 1986, and in Fukushima, in 2011, there has been a great deal of public concern about the health effects of long-term and low-dose radiation exposure and contamination. The health risks to workers who have been occupationally exposed to radiation has been a serious concern from the points of view of our understanding of low-dose radiation biology and oncology. In general, the energy deposition of ionizing radiation is localized along its track, resulting in a heterogeneous distribution of exposed or unexposed cells within an irradiated organ. This situation differs substantially from that in higher dose regions when analysed by the concept of "absorbed dose." Instead, an "elemental dose," given by a single radiation track to a target volume, as developed by microdosimetry, should be used to analysis low-dose effects (International Commission on Radiation Units and Measurements 1983). This dose considerably differs from the low- to high-linear energy transfer (LET) radiations, for example, they were respectively estimated as 0.87 and $39 \mathrm{mGy}$ for ${ }^{60} \mathrm{Co} \gamma$-rays and $14 \mathrm{MeV}$ neutrons by Booz and Feinendegen in 1988 (Booz \& Feinendegen 1988). In this low-dose exposure, two groups exist in a cell population; one consists of cells that received the elemental dose from a single track, and the other consists of cells that did not receive any dose. Therefore, we need to assess this characteristic of low-dose radiation effects on living systems.

To date, low-dose effects on biological homeostasis including spermatogenesis, remain unclear and continue to attract controversy in the fields of radiation protection and 
radiobiology (Morgan and Bair, 2013; Tomita and Maeda, 2015). In addition, transgenerational effects from SSCs exposed to radiation also remain to be fully determined with some animal and epidemiological studies suggesting a paternal influence on the future health of offspring (Soubry et al. 2014). These stochastic effects, which could be induced by low-dose irradiated germ cells, are potential threats not only for present but also next generations. In this context, further radiation studies are required to confirm the potential low-dose radiation-induced effects; deterministic effects (i.e., temporal infertility and permanent sterility) and stochastic effects (i.e., carcinogenesis and heritable effects). To discuss low-dose radiation-induced risks to the maintenance of male fertility, in this review, the authors summarise the literature, mainly focusing on mechanisms of low-dose radiation-induced damage on spermatogenesis, epidemiological studies of environmental radiation effects on sperm parameters and transgenerational effects from SSCs exposure to radiation.

\section{Mechanisms of low-dose radiation-induced damage on spermatogenesis}

\subsection{Apoptosis and DNA double strand breaks repair in spermatogenesis}

Human spermatogenesis is a process that lasts for approximately 60-70 days which results in the, transformation of spermatogonia through primary spermatocytes, secondary spermatocytes and spermatids to spermatozoa which then mature in the epididymis. During spermatogenesis, low-LET radiation (i.e., $\gamma$ - and X-rays) can directly induce a number of DNA damage lesions including base damage, DNA and DNA-protein crosslinks, SSBs and DSBs in the DNA. Of these DSBs represent the greatest threat to genomic integrity due to difficulties in correct repair. The spermatogenic cells consist of several different subpopulations, such as SSCs and their differentiating progeny (i.e., spermatogonia, spermatocytes, and round spermatids), that vary in their sensitivity to 
radiation (Rübe et al. 2011). This may be due to the various cell types having clearly different chromatin compositions and as a result require different repair proteins and mechanism of repair to restore genomic integrity following (Rübe et al. 2011; GonzálezMarín et al. 2012). Failure of the DNA damage results in de novo mutationin the germ cell line (Wang et al. 2012) driving a number of biological conseqeuences

Apoptosis is an important physiological mechanism that frequently occurs in the testis to limit the number of germ cells in the seminiferous epithelium (Lee et al. 1997). It has been found clinically that men with abnormal sperm parameters display higher levels of the apoptotic protein Fas on ejaculated spermatozoa (Sakkas et al. 2003), indicating that selective depletion of abnormal spermatozoa is controlled by apoptosis. In response to radiation, $\gamma-\mathrm{H} 2 \mathrm{AX}$ (phosphorylated histone $\mathrm{H} 2 \mathrm{AX}$ ) foci are generated in spermatogonia, spermatocytes and round spermatids (Hamer et al. 2003). $\gamma$-H2AX has a critical role in the recruitment of DNA repair factors and DNA damage-signaling proteins including tumor suppressor p53, a key protein with aa central role in DNA damageinduced apoptosis. In irradiated spermatogonia, $\gamma-\mathrm{H} 2 \mathrm{AX}$ interacts with $\mathrm{p} 53$ to induce spermatogonial apoptosis (Hamer et al. 2003). A previous study showed that even at very low doses $(10 \mathrm{mGy})$ is induced in spermatogonia caused the arrest of spermtatogenesis (Grewenig et al. 2015).

SSCs are characterized by a complete lack of compacted heterochromatin. In these cells, DNA damage detection and signaling is mediated in the absence of the transducer complex $\gamma$-H2AX/MDC1, and radiation-induced DSBs are repaired predominantly through DNA-dependent protein kinase catalytic subunit (DNA-PKcs) independent mechanisms (Rübe et al. 2011). In response to genotoxic insults, effective cell cycle checkpoints in the differentiating progeny, but not in SSCs themselves, eliminate damaged cells by apoptosis ensuring only intact genetic information is transmitted to 
subsequent generations (Rübe et al. 2011).

As shown in Figure 2, At the onset of first meiotic prophase, chromosomes receive Spo11-dependent DSBs that are repaired by homologous recombination (HR) to promote crossing over and ensure homolog separation during the meiosis I division (Bannister \& Schimenti 2004; Ahmed et al. 2013). In contrast to HR, non-homologous end joining (NHEJ), the major DSB repair mechanism during the G1 cell cycle phase, is downregulated during early meiotic prophase (Ahmed et al. 2013). The classical DNAPK dependent NHEJ pathway involving the DNA-PKcs which is recruited by the Ku70 and $\mathrm{Ku} 80$ proteins to the site of damage and subsequently, both end-positioned $\mathrm{Ku}$ and DNA PKcs mediate the recruitment of XRCC4/DNA ligase IV complex (González-Marín et al. 2012). NHEJ appears to contribute to the repair of replication-dependent and radiation-induced DNA damage in somatic testis cells and may also be required for the repair of persistent Spo11-dependent and radiation-induced DSBs in late spermatocytes (Ahmed et al. 2013). However, studies using DNA-PKcs deficient round spermatids of SCID mice have shown almost identical DSB repair kinetics to those of DNA-PKcs proficient spermatids, indicating the slow and incomplete DSB repair in round spermatids is independent of the classical DNA-PK dependent NHEJ (Rübe et al. 2011; González-Marín et al. 2012).

\subsection{Reactive oxygen species}

A possible mechanism of DNA damage induced by low-doses is through the production of reactive oxygen species (ROS) as ionizing radiation exposures lead to oxidizing events which alter molecular structures directly or via products of water radiolysis (Azzam et al. 2012). Not only direct but also indirect interactions with 
macromolecules have been shown to occur at low doses (Boucher et al. 2006). ROS can be generated in cells by endogenous and exogenous stimuli. Endogenous production of ROS arises mainly from leaks during mitochondrial electron transport chain activity (Dickinson \& Chang 2011). The generation of ROS in cells exists in equilibrium with a wide variety of antioxidant defences such as glutathione, however, if the antioxidant detoxification systems fail to maintain ROS within tolerated levels, excess ROS can be deleterious (Redza-Dutordoir \& Averill-Bates 2016).

Several forms of damage to sperm DNA are caused by ROS including chromatin cross-linking, chromosome deletion, DNA strand breaks and base oxidation (Agarwal \& Said 2005). ROS are also important in mediating apoptosis by inducing cytochrome c release and activation of caspases 9 and 3 (Said 2004). The enhancement of ROS levels to high levels in semen produced by abnormal spermatozoa are a main cause of decreased fertility in the case of teratozoospermia (Rato et al. 2012; Sabeti et al. 2016). These data suggest low-dose effects on spermatogenesis are mediated via elevated ROS levels in sperm forming cells.

\subsection{Radiation-induced bystander signalling}

The classical radiobiology paradigm considers radiation effects to be limited only to the cells directly traversed by radiation fields, however, several recent studies have shown radiation-induced bystander signalling in various cellular systems using a range of end points (Nagasawa \& Little 1999; Prise et al. 2003; Prise \& O’Sullivan 2009; Kadhim et al. 2013). A simple definition of radiation-induced bystander effect (RIBE) is one in which "cells that did not directly receive radiation doses but did receive signals from neighbouring irradiated cells behave as though they have been exposed, showing genomic instability and other abnormalities.”. The effects are mediated either through 
gap junctions or via soluble factors released by irradiated cells, such as TGF- $\beta$, TNF- $\alpha$, IL-8, nitric oxide, membrane signalling, DNA fragments, and ROS (Blyth \& Sykes 2011). Other defined types of bystander signalling are abscopal and cohort effects. Abscopal effects are defined as communication between irradiated and un-irradiated tissues outside of the irradiated volume either directly or via systemic signalling. In contrast, cohort effects occur between irradiated cells within an irradiated volume (Blyth \& Sykes 2011; Butterworth et al. 2013). The RIBE represent a paradigm shift in our understanding of the biological effects of ionizing radiation where extra-nuclear and extracellular events may contribute to the final biological consequences of exposure to low doses of radiation (Hei et al. 2008) which have consequences for current models of radiation risk. This suggests that physical dose and its targets within irradiated tissues may not be the sole driver of carcinogenic pathways and that cell-cell signalling processes between exposed and non-exposed cells may be important (Prise \& O’Sullivan, 2009).

Since the RIBE was first reported by Nagasawa and Little (1992), low-dose research has been undertaken using a variety of experimental systems and suggests that DNA damage and genetic instability play a significant role in the effects of low-dose radiation on cells (Kadhim et al. 2013). A key characteristic of RIBE, in contrast to direct irradiation effects, is the dose-response relationship. Instead of an increased response with an increasing radiation dose, the RIBE becomes saturated at relatively low doses (typically less than 1 Gy) (Prise \& O'Sullivan 2009). The RIBE is strictly a low-dose phenomenon, since at high doses the bystander effect observed at low doses will be largely overshadowed by direct damage to cells (Hei et al. 2008; Asur et al. 2015), nevertheless some evidence has suggested that even direct effects have a component of bystander signalling (McMahon et al. 2012). It should be also noted that protective bystander or adaptive responses encompassing DNA repair and antioxidation reactions 
may be induced following exposures to low doses of sparsely ionizing radiations such as X- and $\gamma$-rays (Azzam et al. 2016). The protective mechanisms may stimulate good responses that enhance the well-being of the organism after the exposure. In fact, Using a ${ }^{3} \mathrm{He}^{2+}$ charged particle microbeam, Belyakov and colleagues showed a significant level of bystander-induced differentiation and apoptosis in primary urothelial explants (Belyakov et al. 2002). Therefore, at low doses, an effect of RIBE on the sperm-forming cells could be predicted, however, evidence for this and the specifics of any biological mechanism remain unclear, and further research is needed.

\section{Epidemiological studies of environmental radiation effects on sperm}

\subsection{Occupational irradiation}

The earliest report of occupational exposure related to fertility was made by Percivall Pott in 1775 who observed a high incidence of skin cancer on the testicles in chimney sweeps (Sheiner et al. 2003). This was supported by a significant amount of laboratory data obtained in animal models exposed to radiation, however, there is a paucity of human epidemiological data related to occupationally exposed radiation (Schull 1984).

In 2013, an epidemiological study of 83 health workers who had been occupationally exposed to radiation clarified the effects observed in spermatozoa which showed changes in motility characteristics, increased sperm morphological abnormalities, sperm DNA fragmentation and global hyper methylation were found (Kumar et al. 2013). Three years later, a study of 46 men occupationally exposed also showed decreased sperm motility and abnormal morphology in exposed men. The study also showed significantly higher DNA fragmentation index in exposed compared to non-exposed men (Zhou et al. 
2016). These studies provide new insights into low-dose risks on human sperm characteristics with the caveat of sample size in the studies.

Previous animal and human data suggests that occupational radiation exposure may have a substantial effect on sperm characteristics in health workers. The International Commission on Radiological Protection (ICRP), in its 2007 recommendations based on occupational classification, limits artificial irradiation of the public to an average of $<1$ $\mathrm{mSv}$ of effective dose per year, and $<20 \mathrm{mSv}$ per year in the case of occupationally exposed subjects (ICRP 2007). Further epidemiological and biostatistical studies are needed amongst large populations to address the reproductive problems of occupationally exposed workers (Kumar et al. 2013).

\subsection{Chernobyl nuclear accident}

On 26 April 1986, the Number 4 reactor of the Chernobyl Nuclear Power Plant, in Ukraine, suffered a steam explosion that blew the lid of the reactor and resulted in the largest accidental release of radioactivity into the environment in the human history (IAEA 2006). Prior to the Chernobyl accident, mammals were perceived to be among the most radiosensitive taxonomic groups (Geras'kin et al. 2008; Beresford et al. 2016). A series of studies of rodents in highly contaminated sites (average dose up to $830 \mathrm{mGy} / \mathrm{h}$ ) found no clear evidence of genetic changes compared to control sites (Baker et al. 2001; Wickliffe et al. 2002), although a study in Belarus at much lower dose rates (up to 30 mGy/day) found an increased frequency of chromosome aberrations (Goncharova \& Ryabokon 1995; Beresford et al. 2016).

According to an investigation of sperm parameters in 125 workers involved in the clean-up of the Chernobyl nuclear disaster and irradiated by doses up to $250 \mathrm{mSv}$, significant changes of sperm counts and morphology were found in the population exposed to radiation (Cheburakov \& Cheburakova 1993). In addition, a pilot study of 18 
individuals engaged in clean-up operations after the accident indicated that decreases in motility and increases of malformations were found in the spermatozoa samples taken from workers, when compared with control subjects (Fischbein et al. 1997). Dose levels of irradiated individuals were not clearly reported in the latter study.

After the Chernobyl accident, there was a great deal of social concern about environmental radioisotope contamination and radiation-induced effects on human health (Rahu 2003), however, there seem to be few resultant international epidemiological studies. Though more than 30 years have now passed, further studies are needed to investigate the low-dose radiation-induced effects on male reproductive systems that resulted from the world's worst nuclear accident.

\subsection{Fukushima nuclear accident}

On 11 March 2011, a devastating earthquake and resulting tsunami caused serious damage to various areas of the Pacific coast in Japan's Fukushima Prefecture and all residents feared the meltdown of the Fukushima Daiichi Nuclear Power Plant's reactors (Shibahara 2011; Fukunaga 2015).

In contrast to the Chernobyl accident, the Fukushima accident has, to date, resulted in no deterministic effects and no worker deaths; furthermore, the current estimates of the population's radiation exposure doses are also much lower (and the distribution band much narrower) than the doses for which cancer excesses have been detected among atomic bomb survivors after 60 years of follow-up (Boice 2012). It would be difficult to detect any low-dose radiation-induced effect on male reproductive potential among men from this area.

A 2016 study showed that, although the median concentrations of ${ }^{134} \mathrm{Cs}$ and ${ }^{137} \mathrm{Cs}$ in the mice from Fukushima exceeded 4,000 Bq/kg, there were no significant differences in the apoptotic cell frequencies or the frequencies of morphologically abnormal sperm 
among the capture sites (Okano et al. 2016). The authors concluded that radiation did not cause substantial male subfertility in Fukushima during 2013 and 2014, and radionuclide pollution levels in the study sites would not be detrimental to the spermatogenesis of wild mice in Fukushima. However, a 2017 study of male large Japanese field mice captured in Fukushima after the nuclear disaster showed the numbers of spermatogenic cells, proliferating cell nuclear antigen (PCNA)-positive cells, and TUNEL-positive apoptotic cells per seminiferous tubule, suggesting that enhanced spermatogenesis occurred in large Japanese field mice living in and around the FNPP ex-evacuation zone (Takino et al. 2017). In this study, external dose rate from radiocesium (combined 134Cs and 137Cs) in these animals at the sampling sites exhibited $21 \mu \mathrm{Gy} /$ day, 304-365 $\mu \mathrm{Gy} /$ day, and 407$447 \mu \mathrm{Gy} /$ day.

\section{Transgenerational effects from paternal exposures}

In 1974, Jacqueline Fabia and Truong Dam Thuy reported that paternal occupational exposure to chemical substances can affect the integrity of spermatogenesis and potentially result in the transmission of carcinogenic defects to the children (Fabia \& Thuy 1974). In 2000, a landmark study showed that transgenerational effects from paternal exposures extends to the germ line of unexposed first generation offspring in mice, as revealed by an increased instability of repeat-DNA sequences in their descendants (Dubrova et al. 2000). Both genomic and epigenetic pathways have been suggested to explain the transmissible effects of environmental contaminants, including sperm DNA mutations, genomic instability, suppression of germ-cell apoptosis, and imprinting errors (Cordier 2008; Soubry et al. 2014). Several animal studies have showed evidence for transgenerational epigenetic effects from paternal exposure to radiation (Barber et al. 2002; Shiraishi et al. 2002; Koturbash et al. 2006; Cordier 2008; Mughal et al. 2012; Little et al. 2013; Paris et al. 2015). 
To our knowledge, for humans, the hypothesis of transgenerational effects from paternal exposures to ionizing radiation has long been controversial. Public concerns in the 1980s the UK government to investigate the excess of malignant diseases in children living in the vicinity of the Sellafield nuclear power plant, and a population-based analysis showed the high incidence of leukemia and lymphoma in the young residents of Seascale, which is near the Sellafield plant, compared to those in national registries and surrounding areas (Draper et al. 1993; Soubry et al. 2014). In addition, a case-control study indicated that children of fathers working at the nuclear plant at that time of conception had a three times higher risks of leukemia or Non-Hodgkin's lymphoma (NHL) before the age of 25 (Gardner et al. 1990). According to the 2016 report of Committee on Medical Aspects of Radiation in the Environment (COMARE 2016), on the basis of two or three cases of leukemia and two cases of NHL diagnosed near the Sellafield between 1971 and 2006, when three rather than two observed cases of leukaemia are adopted, the observed number of five cases of leukemia and NHL diagnosed among those born in Seascale during 19502006 and diagnosed while 0-24 years of age during 1971-2006 compares with an expected number of 0.904 , which is a highly significant excess $(p=0.005)$. The standardized incidence ratio is 5.53 (95\% CI, 1.80-12.91), although these risks are no longer detectable in the population from recent studies (COMARE 2016). Also, according to studies on atomic bomb survivors in Japan, no evidence was found for increased cancer incidence in children from exposed fathers (Yoshimoto et al. 1990; Kodaira et al. 1995; Izumi et al. 2003). Furthermore, in clinical practice, a Danish case-cohort study showed mutagenic chemotherapy and radiotherapy doses to the gonads were not associated with genetic defects in children of cancer survivors, although larger studies need to be conducted to further explore potential associations between high-dose pelvic irradiation and specific adverse pregnancy outcomes (Winther et al. 2012). Further studies are 
needed to clarify whether human transgenerational effects occur after exposure of the male germ line.

\section{Conclusion and discussion}

During the long and dynamic differentiation process of spermatogenesis, spermforming cells can potentially be affected by low-dose radiation through a number of possible mechanisms including ROS, radiation-induced bystander signalling and expression of radiosensitivity-related genes. It appears possible that adverse health effects may result in the spermatogenesis of those exposed to low-dose and chronic radiation and contamination via occupational irradiation or nuclear disasters. However, as shown in Table 1, there is as yet, insufficient epidemiological knowledge to assess the risks of lowdose radiation exposure in male reproductive systems. Although such studies have limited chance of providing information on possible health risks following low-dose exposures received gradually over time (Boice 2012), it is the accumulation of many years of solid, methodical research that will lead radiation researchers to the next step and which may help to resolve concerns about low-dose exposures.

The in-depth mechanistic studies of RIBE and individual radiation sensitivity remain unclear, thus there is insufficient basic radiobiological knowledge to assess the risks of low-dose radiation exposure on male reproductive systems. To begin with, the molecular and cellular nature of this specialised microenvironment in the testes remains to be mostly elucidated (Yoshida 2012). However, new radiobiological concepts such as RIBE and individual variation in radiation sensitivity could be important attributes to be exploited for their new insights into low-dose radiation risks and protection.

The availability of new experimental systems should enable faster progress in this field, for example, computer simulations of a network of both cell cycle regulation and DNA damage responses could be a powerful way to predict cellular responses 
(Hattori et al. 2015). Some animal models could also show great promise, such as the Patched-1/Ptch1 heterozygous mouse has been used to show the tumourigenic potential of abscopal effects (Mancuso et al. 2008; Butterworth et al. 2013; Paris et al. 2015). In addition, recent technical developments in reproductive biology could be helpful to clarify the relationship between low-dose radiation exposure and spermatogenesis. In 2011, Japanese researchers succeeded in producing functional sperm from SSCs with the testis of mouse using an organ culture method, which was the first demonstration of mammalian ex vivo spermatogenesis (Sato, Katagiri, Gohbara, et al. 2011). By adding further improvements (Sato, Katagiri, Yokonishi, et al. 2011; Yokonishi et al. 2014; Sato et al. 2015; Komeya et al. 2016), this in vitro technique is now used as the standard model in spermatogonial stem cell research. The use of such functional assays for investigation of low-dose radiation's effect on male reproductive potential may also help to resolve the issue of occupational irradiation or nuclear disasters and transgenerational effects in the male germ line.

Taken together, both the epidemiological and statistical research approaches that focus on sperm quality changes in subjects exposed to low-dose radiation and the lowdose radiation biological research approach that focuses on RIBE or radiosensitivityrelated genes are indispensable. Current concerns and anxieties about the possible effects on human health, including spermatogenesis, from low-dose radiation exposure after the nuclear disasters in Chernobyl and Fukushima should be resolved by future studies comparing both the results of epidemiological and experimental studies. 


\section{Disclosure statement}

The authors report no conflicts of interest. The authors alone are response for the content and writing of the paper.

\section{Acknowledgements}

This work was supported by Nakayama Foundation for Human Science, Yokohama City University Gushinkai Alumni Association, Marubun Research Promotion Foundation. The funding organizations had no role in the design and conduct of the study; in the collection, management, analysis, and interpretation of the data; or in the preparation, review, or approval of the manuscript. 


\section{References}

Agarwal A, Said TM. 2005. Oxidative stress, DNA damage and apoptosis in male infertility: a clinical approach. BJU Int. 95:503-7.

Ahmed EA, Sfeir A, Takai H, Scherthan H. 2013. Ku70 and non-homologous end joining protect testicular cells from DNA damage. J Cell Sci. 126:3095-104.

Asur R, Butterworth KT, Penagaricano JA, Prise KM, Griffin RJ. 2015. High dose bystander effects in spatially fractionated radiation therapy. Cancer Lett. 356:52-7. Azzam EI, Colangelo NW, Domogauer JD, Sharma N, de Toledo SM. 2016. Is Ionizing Radiation Harmful at any Exposure? An Echo That Continues to Vibrate. Health Phys. 110:249-51.

Azzam EI, Jay-Gerin J-P, Pain D. 2012. Ionizing radiation-induced metabolic oxidative stress and prolonged cell injury. Cancer Lett. 327:48-60.

Baker RJ, Bickham AM, Bondarkov M, Gaschak SP, Matson CW, Rodgers BE, Wickliffe JK, Chesser RK. 2001. Consequences of polluted environments on population structure: the bank vole (Clethrionomys glareolus) at Chornobyl. Ecotoxicology. $10: 211-6$.

Bannister LA, Schimenti JC. 2004. Homologous recombinational repair proteins in mouse meiosis. Cytogenet Genome Res. 107:191-200.

Barber R, Plumb MA, Boulton E, Roux I, Dubrova YE. 2002. Elevated mutation rates in the germ line of first- and second-generation offspring of irradiated male mice. Proc Natl Acad Sci U S A. 99:6877-82.

Belyakov O V, Folkard M, Mothersill C, Prise KM, Michael BD. 2002. Bystanderinduced apoptosis and premature differentiation in primary urothelial explants after charged particle microbeam irradiation. Radiat Prot Dosimetry [Internet]. [cited 2017 May 10]; 99:249-51. Available from: http://www.ncbi.nlm.nih.gov/pubmed/12194297 
Beresford NA, Fesenko S, Konoplev A, Skuterud L, Smith JT, Voigt G. 2016. Thirty years after the Chernobyl accident: What lessons have we learnt? J Environ Radioact. 157:77-89.

Blyth BJ, Sykes PJ. 2011. Radiation-induced bystander effects: what are they, and how relevant are they to human radiation exposures? Radiat Res. 176:139-57.

Boice JD. 2012. Radiation epidemiology: a perspective on Fukushima. J Radiol Prot. 32:N33-40.

Bonde JP. 2010. Male reproductive organs are at risk from environmental hazards. Asian J Androl. 12:152-6.

Booz J, Feinendegen LE. 1988. A microdosimetric understanding of low-dose radiation effects. Int J Radiat Biol Relat Stud Phys Chem Med. 53:13-21.

Boucher D, Testard I, Averbeck D. 2006. Low levels of clustered oxidative DNA damage induced at low and high LET irradiation in mammalian cells. Radiat Environ Biophys. 45:267-76.

Butterworth KT, McMahon SJ, Hounsell AR, O’Sullivan JM, Prise KM. 2013. Bystander Signalling: Exploring Clinical Relevance Through New Approaches and New Models. Clin Oncol. 25:586-92.

Cheburakov II, Cheburakova OP. 1993. Disorders of spermatogenesis in people working at the clean-up of the Chernobyl nuclear power plant accident. Radiatsionnaia Biol Radioecol. 33:771-4.

Clermont Y. 1972. Kinetics of spermatogenesis in mammals: seminiferous epithelium cycle and spermatogonial renewal. Physiol Rev. 52:198-236.

Clifton DK, Bremner WJ. 1983. The effect of testicular x-irradiation on spermatogenesis in man. A comparison with the mouse. J Androl. 4:387-92. 
Committee on Medical Aspects of Radiation in the Environment (COMARE). 2016. Further consideration of the incidence of cancers aroud the nuclear installations at Sellafield and Dounreary. COMARE 17th report. [place unknown]: Public Health England for the Committee on Medical Aspects of Radiation in the Environment. Cordier S. 2008. Evidence for a role of paternal exposures in developmental toxicity. Basic Clin Pharmacol Toxicol. 102:176-81.

Dickinson BC, Chang CJ. 2011. Chemistry and biology of reactive oxygen species in signaling or stress responses. Nat Chem Biol. 7:504-11.

Doll R. 1995. Hazards of ionising radiation: 100 years of observations on man. Br J Cancer. 72:1339-49.

Douple EB, Mabuchi K, Cullings HM, Preston DL, Kodama K, Shimizu Y, Fujiwara S, Shore RE. 2011. Long-term radiation-related health effects in a unique human population: lessons learned from the atomic bomb survivors of Hiroshima and Nagasaki. Disaster Med Public Health Prep. 5 Suppl 1:S122-33.

Draper GJ, Stiller CA, Cartwright RA, Craft AW, Vincent TJ. 1993. Cancer in Cumbria and in the vicinity of the Sellafield nuclear installation, 1963-90. BMJ. 306:89-94.

Dubrova YE, Plumb M, Gutierrez B, Boulton E, Jeffreys AJ. 2000. Transgenerational mutation by radiation. Nature. 405:37.

Egerton FN. 2006. A History of the Ecological Sciences, Part 19: Leeuwenhoek's Microscopic Natural History. Bull Ecol Soc Am. 87:47-58.

Fabia J, Thuy TD. 1974. Occupation of father at time of birth of children dying of malignant diseases. Br J Prev Soc Med. 28:98-100.

Fischbein A, Zabludovsky N, Eltes F, Grischenko V, Bartoov B. 1997. Ultramorphological sperm characteristics in the risk assessment of health effects after 
radiation exposure among salvage workers in Chernobyl. Environ Health Perspect. 105 Suppl:1445-9.

Fukunaga H. 2015. After the earthquake, tsunami and nuclear crisis. J R Soc Med. $108: 151-2$.

Gardner MJ, Snee MP, Hall AJ, Powell CA, Downes S, Terrell JD. 1990. Results of case-control study of leukaemia and lymphoma among young people near Sellafield nuclear plant in West Cumbria. BMJ. 300:423-9.

Geras'kin SA, Fesenko S V, Alexakhin RM. 2008. Effects of non-human species irradiation after the Chernobyl NPP accident. Environ Int. 34:880-97.

Goncharova RI, Ryabokon NI. 1995. Dynamics of Cytogenetic Injuries in Natural Populations of Bank Vole in the Republic of Belarus. Radiat Prot Dosimetry. 62:37-40. González-Marín C, Gosálvez J, Roy R. 2012. Types, causes, detection and repair of DNA fragmentation in animal and human sperm cells. Int J Mol Sci. 13:14026-52. Grewenig A, Schuler N, Rübe CE. 2015. Persistent DNA Damage in Spermatogonial Stem Cells After Fractionated Low-Dose Irradiation of Testicular Tissue. Int J Radiat Oncol Biol Phys. 92:1123-31.

Griswold MD. 2016. Spermatogenesis: The Commitment to Meiosis. Physiol Rev. $96: 1-17$.

Hamer G, Roepers-Gajadien HL, van Duyn-Goedhart A, Gademan IS, Kal HB, van Buul PPW, de Rooij DG. 2003. DNA double-strand breaks and gamma-H2AX signaling in the testis. Biol Reprod. 68:628-34.

Hattori Y, Suzuki M, Funayama T, Kobayashi Y, Yokoya A, Watanabe R. 2015. A mathematical model of radiation-induced responses in a cellular population including cell-to-cell communications. Radiat Prot Dosimetry. 166:142-7. 
Hei TK, Zhou H, Ivanov VN, Hong M, Lieberman HB, Brenner DJ, Amundson SA, Geard CR. 2008. Mechanism of radiation-induced bystander effects: a unifying model. J Pharm Pharmacol. 60:943-50.

International Atomic Energy Agency. 2006. Environmental Consequences of the Chernobyl Accident and their Remediation: Twenty Years of Experience. Vienna. International Commission on Radiation Units and Measurements. 1983.

Microdosimetry (Report 36). Bethesda, MD: International Commission on Radiation Units and Measurements, Inc.

International Commission on Radiological Protection. 2007. The 2007

Recommendations of the International Commission on Radiological Protection. ICRP publication 103. Ann ICRP. 37:1-332.

Izumi S, Koyama K, Soda M, Suyama A. 2003. Cancer incidence in children and young adults did not increase relative to parental exposure to atomic bombs. Br J Cancer. 89:1709-13.

Jeruss JS, Woodruff TK. 2009. Preservation of Fertility in Patients with Cancer. N Engl J Med. 360:902-11.

Kadhim M, Salomaa S, Wright E, Hildebrandt G, Belyakov O V, Prise KM, Little MP. 2013. Non-targeted effects of ionising radiation--implications for low dose risk. Mutat Res [Internet]. [cited 2016 Oct 26]; 752:84-98. Available from:

http://www.ncbi.nlm.nih.gov/pubmed/23262375

Kamiya K, Ozasa K, Akiba S, Niwa O, Kodama K, Takamura N, Zaharieva EK, Kimura Y, Wakeford R. 2015. Long-term effects of radiation exposure on health. Lancet. 386:469-78. 
Kodaira M, Satoh C, Hiyama K, Toyama K. 1995. Lack of effects of atomic bomb radiation on genetic instability of tandem-repetitive elements in human germ cells. Am J Hum Genet. 57:1275-83.

Komeya M, Kimura H, Nakamura H, Yokonishi T, Sato T, Kojima K, Hayashi K, Katagiri K, Yamanaka H, Sanjo H, et al. 2016. Long-term ex vivo maintenance of testis tissues producing fertile sperm in a microfluidic device. Sci Rep. 6:21472.

Koturbash I, Baker M, Loree J, Kutanzi K, Hudson D, Pogribny I, Sedelnikova O, Bonner W, Kovalchuk O. 2006. Epigenetic dysregulation underlies radiation-induced transgenerational genome instability in vivo. Int J Radiat Oncol Biol Phys. 66:327-30. Kumar D, Salian SR, Kalthur G, Uppangala S, Kumari S, Challapalli S, Chandraguthi SG, Krishnamurthy H, Jain N, Kumar P, Adiga SK. 2013. Semen abnormalities, sperm DNA damage and global hypermethylation in health workers occupationally exposed to ionizing radiation. PLoS One. 8:e69927.

Lee J, Richburg JH, Younkin SC, Boekelheide K. 1997. The Fas system is a key regulator of germ cell apoptosis in the testis. Endocrinology. 138:2081-8.

Little JB. 2000. Radiation carcinogenesis. Carcinogenesis. 21:397-404.

Little MP. 2009. Cancer and non-cancer effects in Japanese atomic bomb survivors. J Radiol Prot. 29:A43-59.

Little MP, Goodhead DT, Bridges BA, Bouffler SD. 2013. Evidence relevant to untargeted and transgenerational effects in the offspring of irradiated parents. Mutat Res. 753:50-67.

Mancuso M, Pasquali E, Leonardi S, Tanori M, Rebessi S, Di Majo V, Pazzaglia S, Toni MP, Pimpinella M, Covelli V, Saran A. 2008. Oncogenic bystander radiation effects in Patched heterozygous mouse cerebellum. Proc Natl Acad Sci U S A. 105:12445-50. 
McMahon SJ, Butterworth KT, McGarry CK, Trainor C, O’Sullivan JM, Hounsell AR, Prise KM. 2012. A computational model of cellular response to modulated radiation fields. Int J Radiat Oncol Biol Phys. 84:250-6.

Meistrich ML. 2013. Effects of chemotherapy and radiotherapy on spermatogenesis in humans. Fertil Steril. 100:1180-6.

Meistrich ML, Hunter NR, Suzuki N, Trostle PK, Withers HR. 1978. Gradual regeneration of mouse testicular stem cells after exposure to ionizing radiation. Radiat Res. 74:349-62.

Morgan WF, Bair WJ. 2013. Issues in low dose radiation biology: the controversy continues. A perspective. Radiat Res. 179:501-10.

Mortimer D, Barratt CLR, Björndahl L, de Jager C, Jequier AM, Muller CH. 2013. What should it take to describe a substance or product as "sperm-safe." Hum Reprod Update. 19 Suppl 1:i1-45.

Moss JL, Choi AW, Fitzgerald Keeter MK, Brannigan RE. 2016. Male adolescent fertility preservation. Fertil Steril. 105:267-73.

Mughal SK, Myazin AE, Zhavoronkov LP, Rubanovich A V, Dubrova YE. 2012. The dose and dose-rate effects of paternal irradiation on transgenerational instability in mice: a radiotherapy connection. PLoS One. 7:e41300.

Muller HJ. 1927. ARTIFICIAL TRANSMUTATION OF THE GENE. Science (80- ). $66: 84-7$.

Nagasawa H, Little JB. 1999. Unexpected sensitivity to the induction of mutations by very low doses of alpha-particle radiation: evidence for a bystander effect. Radiat Res. $152: 552-7$. 
National Research Council (US) Committee on the Biological Effects of Ionizing Radiation (BEIR V). 1990. Health Effects of Exposure to Low Levels of Ionizing Radiation: Beir V. [place unknown].

Okano T, Ishiniwa H, Onuma M, Shindo J, Yokohata Y, Tamaoki M. 2016. Effects of environmental radiation on testes and spermatogenesis in wild large Japanese field mice (Apodemus speciosus) from Fukushima. Sci Rep. 6:23601.

Paris L, Giardullo P, Leonardi S, Tanno B, Meschini R, Cordelli E, Benassi B, Longobardi MG, Izzotti A, Pulliero A, et al. 2015. Transgenerational inheritance of enhanced susceptibility to radiation-induced medulloblastoma in newborn Ptch $1^{+} /^{-}$mice after paternal irradiation. Oncotarget. 6:36098-112.

Prise KM, Folkard M, Michael BD. 2003. Bystander responses induced by low LET radiation. Oncogene. 22:7043-9.

Prise KM, O’Sullivan JM. 2009. Radiation-induced bystander signalling in cancer therapy. Nat Rev Cancer. 9:351-60.

Rahu M. 2003. Health effects of the Chernobyl accident: fears, rumours and the truth. Eur J Cancer. 39:295-9.

Rato L, Alves MG, Socorro S, Duarte AI, Cavaco JE, Oliveira PF. 2012. Metabolic regulation is important for spermatogenesis. Nat Rev Urol. 9:330-8. Redza-Dutordoir M, Averill-Bates DA. 2016. Activation of apoptosis signalling pathways by reactive oxygen species. Biochim Biophys Acta. 1863:2977-92. Rowley MJ, Leach DR, Warner GA, Heller CG. 1974. Effect of graded doses of ionizing radiation on the human testis. Radiat Res. 59:665-78.

Rübe CE, Zhang S, Miebach N, Fricke A, Rübe C. 2011. Protecting the heritable genome: DNA damage response mechanisms in spermatogonial stem cells. DNA Repair (Amst). 10:159-68. 
Ruestow EG. 1983. Images and ideas: Leeuwenhoek's perception of the spermatozoa. J Hist Biol. 16:185-224.

Sabeti P, Pourmasumi S, Rahiminia T, Akyash F, Talebi AR. 2016. Etiologies of sperm oxidative stress. Int J Reprod Biomed. 14:231-40.

Said TM. 2004. Role of caspases in male infertility. Hum Reprod Update. 10:39-51.

Sakkas D, Seli E, Bizzaro D, Tarozzi N, Manicardi GC. 2003. Abnormal spermatozoa in the ejaculate: abortive apoptosis and faulty nuclear remodelling during spermatogenesis. Reprod Biomed Online. 7:428-32.

Sato T, Katagiri K, Gohbara A, Inoue K, Ogonuki N, Ogura A, Kubota Y, Ogawa T. 2011. In vitro production of functional sperm in cultured neonatal mouse testes. Nature. 471:504-7.

Sato T, Katagiri K, Yokonishi T, Kubota Y, Inoue K, Ogonuki N, Matoba S, Ogura A, Ogawa T. 2011. In vitro production of fertile sperm from murine spermatogonial stem cell lines. Nat Commun. 2:472.

Sato T, Sakuma T, Yokonishi T, Katagiri K, Kamimura S, Ogonuki N, Ogura A, Yamamoto T, Ogawa T. 2015. Genome Editing in Mouse Spermatogonial Stem Cell Lines Using TALEN and Double-Nicking CRISPR/Cas9. Stem Cell Reports. 5:75-82. Schmitz-Feuerhake I, Busby C, Pflugbeil S. 2016. Genetic radiation risks: a neglected topic in the low dose debate. Environ Health Toxicol. 31:e2016001.

Schull WJ. 1984. Reproductive Problems: Fertility, Teratogenesis, and Mutagenesis. Arch Environ Heal An Int J. 39:207-212.

Shah DJ, Sachs RK, Wilson DJ. 2012. Radiation-induced cancer: a modern view. Br J Radiol. 85:e1166-73.

Sheiner EK, Sheiner E, Hammel RD, Potashnik G, Carel R. 2003. Effect of occupational exposures on male fertility: literature review. Ind Health. 41:55-62. 
Shibahara S. 2011. The 2011 Tohoku Earthquake and Devastating Tsunami. Tohoku J Exp Med. 223:305-7.

Shiraishi K, Shimura T, Taga M, Uematsu N, Gondo Y, Ohtaki M, Kominami R, Niwa O. 2002. Persistent induction of somatic reversions of the pink-eyed unstable mutation in F1 mice born to fathers irradiated at the spermatozoa stage. Radiat Res. 157:661-7. Soubry A, Hoyo C, Jirtle RL, Murphy SK. 2014. A paternal environmental legacy: Evidence for epigenetic inheritance through the male germ line. BioEssays. 36:359-71. Takino S, Yamashiro H, Sugano Y, Fujishima Y, Nakata A, Kasai K, Hayashi G, Urushihara Y, Suzuki M, Shinoda H, et al. 2017. Analysis of the Effect of Chronic and Low-Dose Radiation Exposure on Spermatogenic Cells of Male Large Japanese Field Mice ( Apodemus speciosus ) after the Fukushima Daiichi Nuclear Power Plant Accident. Radiat Res. 187:161-8.

Tomita M, Maeda M. 2015. Mechanisms and biological importance of photon-induced bystander responses: do they have an impact on low-dose radiation responses. J Radiat Res [Internet]. [cited 2016 Oct 26]; 56:205-19. Available from: http://www.ncbi.nlm.nih.gov/pubmed/25361549

Tran S, Boissier R, Perrin J, Karsenty G, Lechevallier E. 2015. Review of the Different Treatments and Management for Prostate Cancer and Fertility. Urology. 86:936-41. Valli H, Phillips BT, Shetty G, Byrne JA, Clark AT, Meistrich ML, Orwig KE. 2014. Germline stem cells: toward the regeneration of spermatogenesis. Fertil Steril. 101:313.

Wang J, Fan HC, Behr B, Quake SR. 2012. Genome-wide Single-Cell Analysis of Recombination Activity and De Novo Mutation Rates in Human Sperm. Cell. 150:40212. 
Wickliffe JK, Chesser RK, Rodgers BE, Baker RJ. 2002. ASSESSING THE

GENOTOXICITY OF CHRONIC ENVIRONMENTAL IRRADIATION BY USING MITOCHONDRIAL DNA HETEROPLASMY IN THE BANK VOLE

(CLETHRIONOMYS GLAREOLUS) AT CHORNOBYL, UKRAINE. Environ Toxicol Chem. 21:1249-54.

Winther JF, Olsen JH, Wu H, Shyr Y, Mulvihill JJ, Stovall M, Nielsen A, Schmiegelow M, Boice JD. 2012. Genetic disease in the children of Danish survivors of childhood and adolescent cancer. J Clin Oncol. 30:27-33.

Withers HR, Hunter N, Barkley HT, Reid BO. 1974. Radiation survival and regeneration characteristics of spermatogenic stem cells of mouse testis. Radiat Res. $57: 88-103$.

Yokonishi T, Sato T, Komeya M, Katagiri K, Kubota Y, Nakabayashi K, Hata K, Inoue K, Ogonuki N, Ogura A, Ogawa T. 2014. Offspring production with sperm grown in vitro from cryopreserved testis tissues. Nat Commun. 5:4320.

Yoshida S. 2012. Elucidating the identity and behavior of spermatogenic stem cells in the mouse testis. Reproduction. 144:293-302.

Yoshimoto Y, Neel J V, Schull WJ, Kato H, Soda M, Eto R, Mabuchi K. 1990. Malignant tumors during the first 2 decades of life in the offspring of atomic bomb survivors. Am J Hum Genet Genet. 46:1041-52.

Zhou DD, Hao JL, Guo KM, Lu CW, Liu XD. 2016. Sperm quality and DNA damage in men from Jilin Province, China, who are occupationally exposed to ionizing radiation. Genet Mol Res. 15. 
Table 1. Environmental radiation effects on sperm characteristics.

\begin{tabular}{|c|c|c|c|}
\hline & Subject & Sperm characteristics change & References \\
\hline \multirow[t]{2}{*}{$\begin{array}{l}\text { Occupational } \\
\text { radiation exposure }\end{array}$} & $\begin{array}{l}83 \text { health workers } \\
\text { occupationally exposed to } \\
\text { ionizing radiation }\end{array}$ & $\begin{array}{l}\text { motility characteristics, } \\
\text { morphological abnormalities, DNA } \\
\text { fragmentation, global } \\
\text { hypermethylation }\end{array}$ & (Kumar et al. 2013) \\
\hline & $\begin{array}{l}46 \text { men occupationally } \\
\text { exposed to ionizing } \\
\text { radiation }\end{array}$ & $\begin{array}{l}\text { motility characteristics, } \\
\text { morphological abnormalities, DNA } \\
\text { fragmentation }\end{array}$ & (Zhou et al. 2016) \\
\hline \multirow[t]{2}{*}{$\begin{array}{l}\text { Chernobyl nuclear } \\
\text { accident }\end{array}$} & $\begin{array}{l}125 \text { workers in the clean- } \\
\text { up of the Chernobyl } \\
\text { nuclear disaster }\end{array}$ & $\begin{array}{l}\text { decrease of sperm counts, } \\
\text { azoospermia, morphological } \\
\text { abnormalities }\end{array}$ & $\begin{array}{l}\text { (Cheburakov and } \\
\text { Cheburakova, 1995) }\end{array}$ \\
\hline & $\begin{array}{l}18 \text { individuals engaged in } \\
\text { clean-up operations after } \\
\text { the Chernobyl nuclear } \\
\text { accident }\end{array}$ & $\begin{array}{l}\text { motility characteristics, } \\
\text { morphological abnormalities }\end{array}$ & (Fischbein et al. 1997) \\
\hline \multirow[t]{2}{*}{$\begin{array}{l}\text { Fukushima nuclear } \\
\text { accident }\end{array}$} & $\begin{array}{l}67 \text { Wild large Japanese } \\
\text { field mice (Apodemus } \\
\text { speciosus) captured in } \\
\text { Fukushima }\end{array}$ & $\begin{array}{l}\text { no significant change or } \\
\text { morphological abnormalities }\end{array}$ & (Okano et al. 2016) \\
\hline & $\begin{array}{l}9 \text { Wild large Japanese } \\
\text { field mice (Apodemus } \\
\text { speciosus) captured in } \\
\text { Fukushima }\end{array}$ & enhancement of spermatogenesis & (Takino et al.2017) \\
\hline
\end{tabular}


Figure 1. Spermatogenesis. Spermatogenesis consists of three different phases; spermatogonial proliferation, meiotic cell division of spermatotocytes into spermatids, and morphological changes of round spermatids into spermatozoa, which is called spermiogenesis. This spermatogenic progression depends on hormonal milieu, created by pituitary and local production of respective hormones.

Figure 2. Apoptosis and DNA double strand breaks repair from the spermatogonial stem cells to round spermatids. 
Figure 1

Pituitary gl.

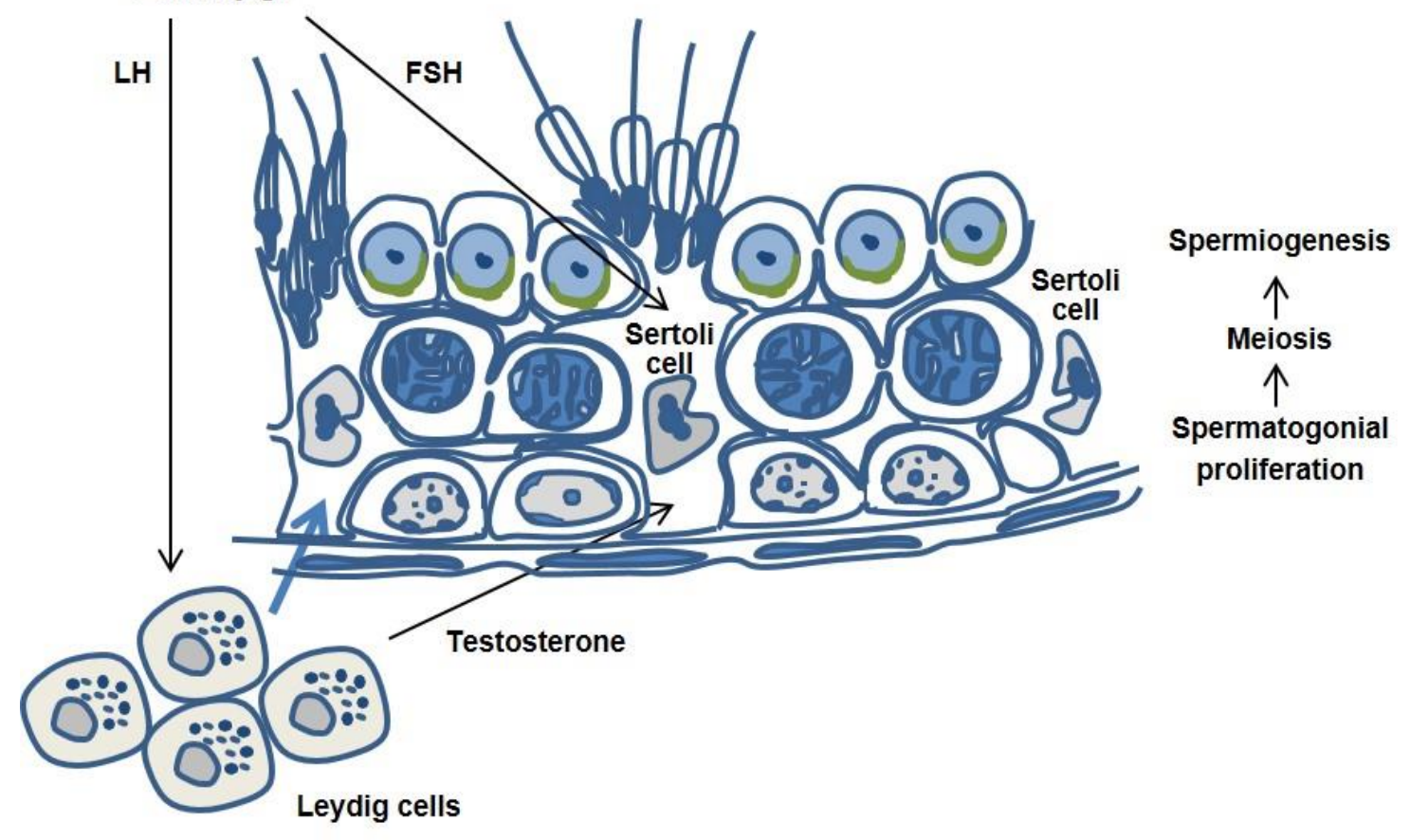


Figure 2

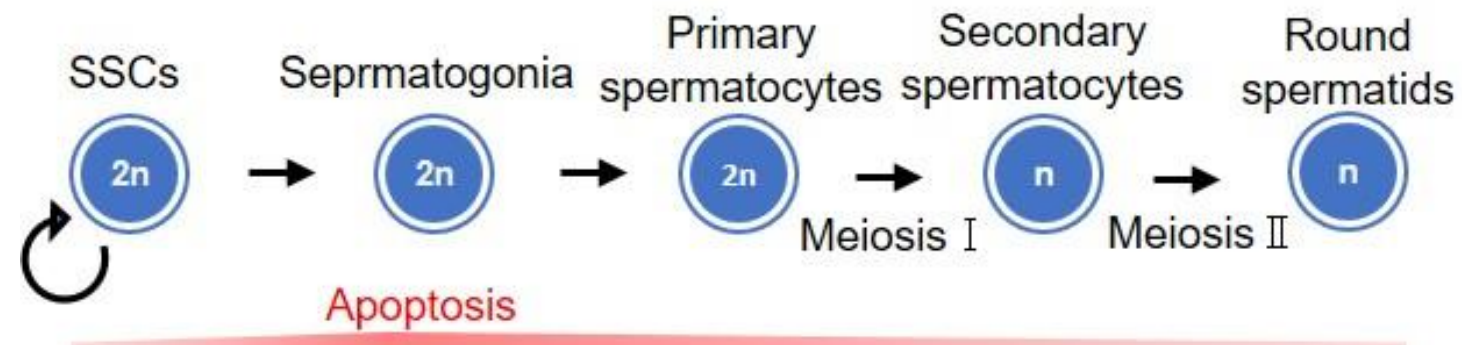

